\title{
Cangkok kulit ketebalan penuh pada vulnus avulsi subfascial di vertebrae regio lumbo-sacral kucing lokal
}

\author{
Yulia Erika \\ Klinik Hewan Zech Vet Care. Jl Sutan Syahrir, Simpang Ikal, Rawang, Padang Selatan, Padang
}

\begin{abstract}
ABSTRAK: Vulnus avulsi merupakan luka yang disertai dengan kerobekan/terlepasnya sebagian jaringan tubuh dan sering mengacu pada trauma permukaan kulit. Tingkat kerusakan kulit dapat mencapai lapisan jaringan subkutan (suprafascial/superficial fascia) hingga jaringan yang lebih dalam meliputi otot, tendon atau tulang (subfascial). Tulisan ini melaporkan kasus luka terbuka di vertebrae regio lumbo-sacral pada kucing domestik. Luka kronis lebih dari satu tahun dan didiagnosa sebagai vulnus avulsi subfascial kronis. Kombinasi pengobatan sistemik telah diberikan selama lebih dari satu tahun on-off dan pengobatan terputus saat kucing bunting hingga melahirkan. Terapi cangkok kulit berhasil dilakukan untuk menghindari kerusakan struktur jaringan kulit yang lebih dalam dan luas. Kucing sudah dapat tidur dengan posisi berbaring normal setelah 2 minggu dan rambut sudah menutupi cangkok kulit setelah 8 minggu.

Kata kunci:

Cangkok kulit ketebalan penuh, kucing lokal, regio lumbo-sacral, vulnus avulsi subfascial
\end{abstract}

\section{- PENDAHULUAN}

Avulsi merupakan cedera yang disertai terlepasnya jaringan akibat trauma atau pembedahan (Fossum 2019). Cedera avulsi yang paling umum adalah avulsi kulit dimana kerobekan lapisan kulit memperlihatkan struktur profundal seperti otot dan tulang. Vulnus avulsi suprafascial dapat diperbaiki dengan penjahitan kulit, namun pada kasus vulnus avulsi subfascial membutuhkan pembedahan rekonstruktif. Cangkok kulit merupakan tindakan memindahkan kulit donor sehat ke bagian luka terbuka (Grabb 1979). Jenis cangkok kulit terdiri atas split-thickness skin grafts (STSG) dan fullthickness skin grafts (FTSG) (Erwin et al. 2016).

Cangkok kulit split mengaplikasikan lapisan paling luar kulit, yaitu epidermis dan sebagian dermis diambil dari bagian tubuh donor untuk dipindahkan ke resipien. Jenis cangkok ini lebih sesuai untuk luka terbuka berukuran besar (White et al. 2003). Sementara pada cangkok kulit ketebalan penuh diambil seluruh lapisan kulit epidermis dan dermis untuk diaplikasikan ke bagian tubuh resipien, termasuk adneksa seperti folikel rambut dan kelenjar keringat. Tindakan ini lebih sesuai untuk luka pada wajah (Sibero 2015). Tulisan ini melaporkan penanganan vulnus avulsi suprafascial pada kucing lokal.

\section{- KASUS}

Anamnesa dan sinyalemen: Seekor kucing lokal betina berusia sekitar 3 tahun ditemukan dengan luka terbuka besar sekitar 12 x $10 \mathrm{~cm}$ (Gambar 1). Kondisi kucing masih mau makan, serta urinasi dan defekasi normal. Pemeriksaan fisik: Vulnus pada regio lumbo-sacral meluas hingga area flank abdomen dextra dan sinistra. Pemeriksaan penunjang: Hematologi dan kimia darah. Diagnosa: Vulnus avulsi subfascial pada regio lumbo-sacral vertebrae. Prognosa: fausta. Terapi: cangkok kulit ketebalan penuh (full-thickness skin grafts).

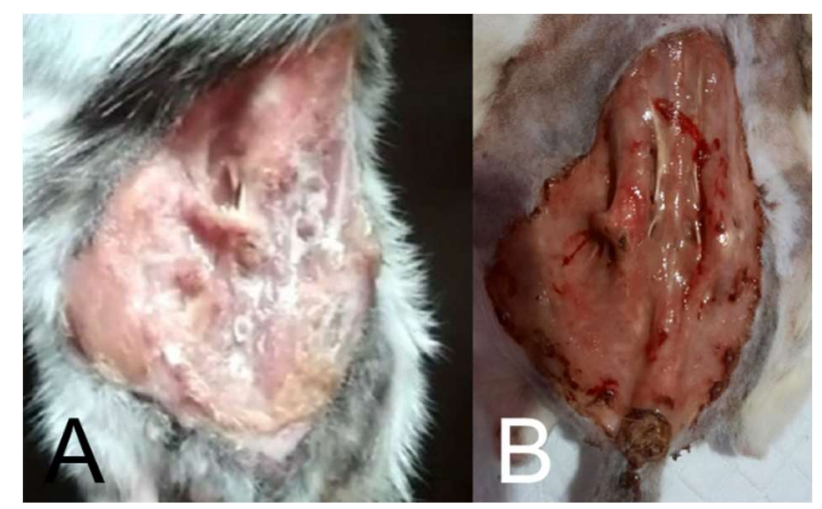

Gambar 1. Vulnus avulsi subfascial pada kucing lokal (A) awal diselamatkan, (B) ulkus dan erosi paska kucing melahirkan.

\section{n HASIL DAN PEMBAHASAN}

Proses cangkok kulit dimulai koleksi kulit donor dari kulit kucing itu sendiri di regio cervical vertebrae. Pembersihan area vulnus dengan $\mathrm{NaCl} 0,9 \%$ dan dilakukan debridement jaringan nekrotik pada luka (Gambar 2). Prosedur dilanjutkan dengan penutupan area vulnus dengan kulit donor yang telah dikoleksi dan penjahitan kulit pola horizontal mattress suture dan simple interrupted suture di beberapa bagian.

Diterima: 05-06-2021 | Direvisi: 15-07-2021 | Disetujui: 20-07-2021 (C) 2021 CC-BY-SA. Ini adalah artikel Open Access yang didistribusikan berdasarkan ketentuan dari Creative Commons Attribution ShareAlike 4.0 International License (https://creativecommons.org/licenses/by-sa/4.0/). 


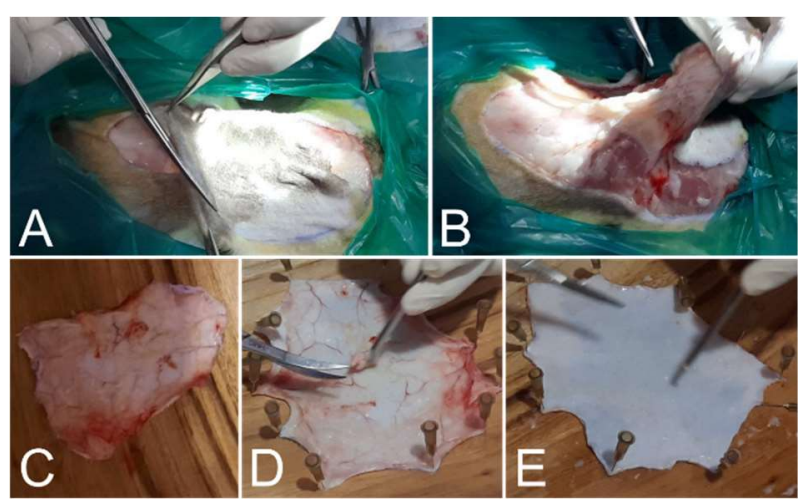

Gambar 2. Pengambilan kulit dari area cervical vertebrae (A, B), kulit cangkok (C), pembersihan kulit (D, E).

Teknik aplikasi kulit donor menggunakan metode cangkok jala (mesh graft technique) (Gambar 3). Teknik ini dipilih mengingat faktor penyebab kegagalan skin graft salah satunya adalah hematoma yang menghalangi revaskularisasi di kulit. Pencegahan hematoma dilakukan dengan membuat insisi dengan jarak secukupnya untuk drainase darah atau eksudat dan untuk memperluas jangkauan skin graft ke bagian tepi bantalan vulnus resipien (Converse et al. 1975).

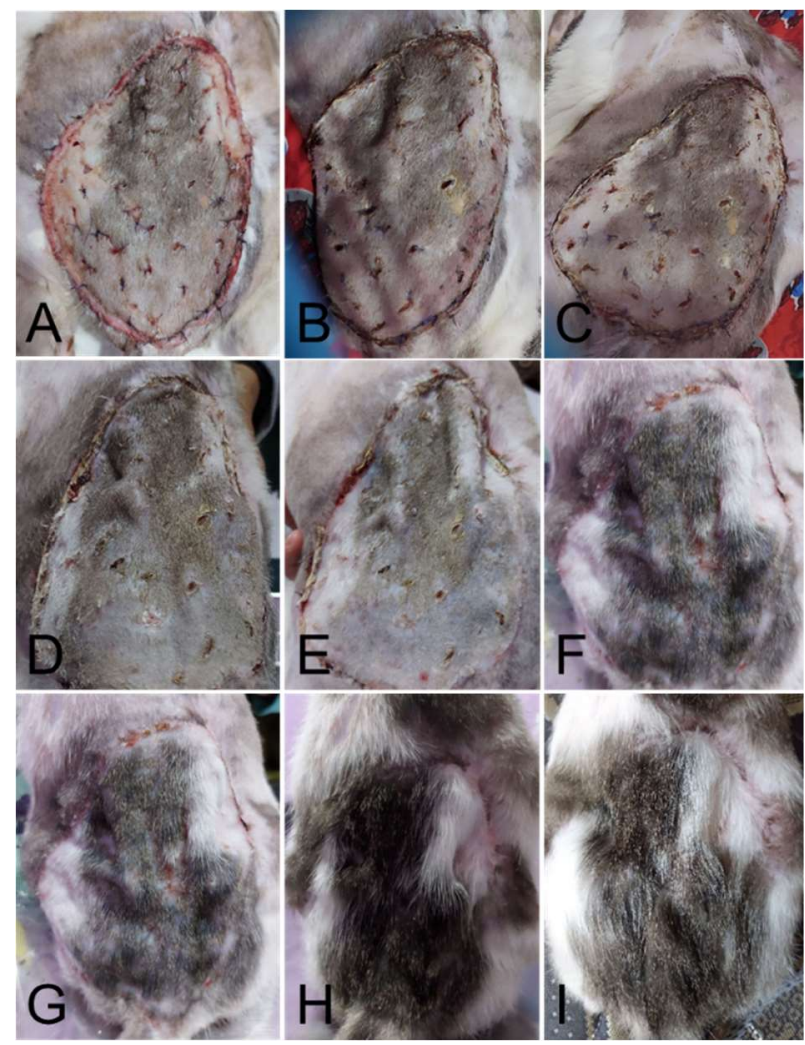

Gambar 3. Status cangkok kulit pascaimplantasi (A), setelah 5 hari (B), 9 hari (C), 2 minggu (D), 3 minggu (E), 4 minggu (F), 1 bulan (G), 2 bulan $(\mathrm{H})$ dan 2,5 bulan (I).

Faktor lainnya yang menyebabkan kegagalan cangkok kulit adalah kegagalan imobilisasi sehingga skin graft bergeser dan revaskularisasi tidak terjadi. Perlekatan kulit donor pada resipien diperkuat dengan simple interrupted suture di setiap celah insisi kecil mesh graft untuk menghindari pergeseran kulit (Nelissen \& White 2014; Or et al. 2017).
Kesuksesan cangkok kulit berhubungan dengan 'graft take' dari kulit donor dan vaskularisasi. Aliran darah dari area wound-bed resipien ke skin graft donor akan melewati fase imbibisi plasmik, inokulasi, dan revaskularisasi (Hinshaw \& Miller 1965). Kesuksesan cangkok kulit juga bergantung pada ada tidaknya infeksi yang dapat diantisipasi dengan antibiotik (Nelissen \& White 2014; Or et al. 2017).

Perkembangan kulit hasil cangkok dengan teknik mesh graft pada kucing ini berlangsung baik. Tidak terdapat komplikasi dan kondisi vital kucing stabil diikuti penambahan berat badan terlihat signifikan. Sebelumnya kucing selalu tidur meringkuk (posisi dorsoventral rekumbensi) dengan kedua kaki belakang ditekuk ke caudal abdomen sehingga kucing sering mengalami kekakuan otot pada kaki belakang. Dua minggu pasca cangkok kulit kucing sudah dapat tidur dengan posisi berbaring normal. Rambut sudah tampak tumbuh dan sempurna menutupi cangkok kulit setelah 8 minggu.

\section{- SIMPULAN}

Cangkok kulit ketebalan penuh dapat digunakan untuk penanganan kasus vulnus avulsi subfascial pada kucing lokal. Kombinasi teknik mesh graft dan diperkuat dengan simple interrupted suture untuk menghindari pergeseran wound bed menjadi faktor pendukung kesuksesan cangkok kulit ini.

\section{INFORMASI PENULIS}

\section{Penulis Korespondensi}

*YE: yuliaerika@rocketmail.com / yuliaerika@gmail.com Zech Vet Care. Jl Sutan Syahrir, Simpang Ikal, Komplek TBO, Blok D/2, Rawang, Padang Selatan. Padang.

\section{- PUSTAKA ACUAN}

Converse JM, Smahel J, Ballantyne DL Jr, Harper AD. 1975. Inosculation of vessels of skin graft and host bed: a fortuitous encounter. British Journal of Plastic Surgery. 28(4):274-282.

Erwin, Gunanti, Handharyani E, Noviana D. 2016. Subjective and objective observation of skin graft recovery on Indonesian local cat with different periods of transplantation time. Veterinary World. 9(5): 481-486.

Fossum TW. 2019. Surgery of the integumentary system. In: Small animal surgery. $5^{\text {th }}$ ed. Philadelphia: Elsevier.

Grabb WC. 1979. Basic techniques in plastic surgery (skin grafts). In: Grabb and Smith's Plastic Surgery. $3^{\text {rd }}$ ed. Boston: Little Brown.

Hinshaw JR, Miller ER. 1965. Histology of healing split-thickness, fullthickness autogenous skin grafts and donor sites. Archives of Surgery. 91(4): 658-670.

Nelissen P, White D. 2014. Flaps and Graft. In: Feline soft tissue and general surgery. Langley-Hob SJ, Demetriou JL, Ladlow JF. St. Louis: Elsevier. pp 195-207.

Or M, Van Goethem B, Kitshoff A, Koenraadt A, Schwarzkopf I, Bosmans T, de Rooster H. 2017. Negative pressure wound therapy using polyvinyl alcohol foam to bolster full-thickness mesh skin graft in dogs. Veterinary Surgery. 46(3):389-395.

Sibero HT. 2015. Full-thickness skin grafts. Jurnal Kedokteran Universitas Lampung. 5(9):81-88.

White N, Hettiaratchy S, Papini RPG. 2003. The choice of splitthickness skin graft donor site: patients' and surgeons' preferences (letter). Plastic and Reconstructive Surgery. 112(3):933-934. 